\title{
Study on the Strategy of Building Shanghai into an International Financial Centre
}

\author{
Zhirun Xiao \\ School of Economics \& Management, Shanghai Second Polytechnic University, Shanghai, China \\ Email: xzrun0213@163.com
}

Received 13 May 2015; accepted 7 July 2015; published 14 July 2015

\begin{abstract}
If china wants to become a financial and economic powerhouse, it has to possess a world-class financial centre. So, it has the particular importance of practical significance to build Shanghai into international financial centre. It is also a research subject having far-reaching influence. This article introduces the background of building Shanghai into international financial centre and illuminates the strategic target and thinking of building Shanghai into international financial centre. And the author analyzes and studies the question of strategic choice of building Shanghai into international financial centre.
\end{abstract}

Keywords

Shanghai, International Financial Centre, Strategy

\section{Introduction}

Since presenting the idea of completing Shanghai into an international financial centre from 1992 to 2020, the next five years has been an important period of strategic opportunities to build Shanghai into an international financial center, as well as a critical period for propulsion, challenges and opportunities. From the current stage of constructing Shanghai into an international financial centre, the current Shanghai has basically established a domestic financial centre as the core of the financial market, the initial formation of a global RMB product innovation, trading, pricing and settlement center. Shanghai international financial center has got a certain scale and influence, but not a high degree of internationalization; limited radiation function will need a further improvemnet and enhancement. Shanghai international financial center is in the open innovation of the inside out, from the scale to focus on the quality of the restructuring period, and the development of the upgradation of the cluster resources to enhance its function.

\section{The Strategic Objective of Building Shanghai into an International Financial Center}

Firstly, Shanghai will be basically completed into an international financial center with RMB products most globally influential, to enhance the international status of the yuan, to enhance financial market pricing, making 
Shanghai become an important place for the center of the global asset pricing and wealth management.

Second is to complete the service of building a moderately prosperous society, to enhance the international competitiveness of China's international financial center economy, making Shanghai become an important platform for China's participation in global resource allocation, the impact of the global economic and financial affairs.

Third is to complete the information technology and high-tech features as an important international financial center, making full use of the Internet, big data and other information technology, the development trend of Shanghai to become the leading international financial center and innovation trends in the forefront.

Fourth is to build with good legal environment and first-class living environment international financial center, Shanghai has become an important gathering place so that the common development of global financial institutions, financial professionals.

Fifth is to complete the Asia-Pacific region accounted for connecting international financial centers in emerging economies and developed economies, making Shanghai a global financial integration is an important space node network [1].

\section{The Strategic Thinking of Building Shanghai into an International Financial Centre}

Construction Shanghai into an international financial center is a national strategy, an important part of China's economic reform. The construction principle of building Shanghai into an international financial center is the development model and the focus should be closely around the recent construction of building a moderately prosperous society.

The development ideas of construction Shanghai into an international financial are: having RMB onshore construction as the core, having the Asia-Pacific region as a foothold to financial reform and innovation pilot area trade as a breakthrough, having "enhancing functionality, building brands," as the focal point for market internationalization, information technology, having the rule of law as the guide, taking the road of development by leaps and bounds.

To this end, Shanghai has determined the construction path: relying on the Shanghai sound financial market system, and driven by the freely convertible renminbi, and the interest rate marketization process, Shanghai becomes the first investment, trade, the development of renminbi financial products center, along with the renminbi increasing degree of internationalization and growing international influence, and gradually developed into one of the international financial centers.

The main principles of the construction Shanghai into an international fin0061ncial center should adhere to are: the combination of International Financial Center and China's financial reform and opening up, promoting the development of Shanghai to serve the country better and the combination of market forces and the role of government, combination of resources and absorbing the incremental development stock resources and accelerate financial innovation, and combination of the strengthen financial regulation [2].

Shanghai international financial center should adhere to market-oriented, international, information technology, the rule of law as the orientation. Marketing is the core task; internationalization is the key to a breakthrough, information technology is the future trend of development, and the rule of law is an important safeguard financial center. Adhering to market-oriented, international, information technology, law as the orientation, the ultimate goal of is to make Shanghai into a city like the London and New York, having in line with international practice, internationally competitive institutional environment.

The pattern of the Shanghai international financial center should make full use of market forces to play a dynamic role in actively promoted by the government, relying on China's sustained, stable development and Shanghai international economic, trade and shipping center and gradually establish favorable conditions and take unconventional catch up with the rapid development of the road. On the construction route, we should make full use of Shanghai's financial markets more complete advantage by further expanding the market function, to innovation and development of RMB financial products, rapidly expand the market size, to build Shanghai into RMB financial product development and trading center. Recent strategic focus is: doing more financial products, expanding financial markets, strengthening financial institutions. 


\section{The Strategic Choice for Building as the Breakthrough of Building an International Financial Centre}

\subsection{Striving to Develop Finance to Promote the Long and Stable Development of China's Economy}

Real evidences indicate that the financial development has the negative correlation on the vitality of GDP's growth. The financial development will plan for macroeconomic fluctuations. The higher degree of financial development is, the more stable of our country' financial development will be. The following is the verification of the relationship between the vitality of GDP's growth and financial development [3].

$$
\text { GDP_vitality }=\alpha+\beta \text { Finance_Development }{ }_{\mathrm{it}}+X_{\mathrm{it}} * \gamma+\eta_{t}+\varepsilon_{\mathrm{it}}
$$

From the estimation results in Table 1, variable finance_development and GDP_growth all have the prominent negative correlation. So the improvement of financial development contributes to reducing the vitality of GDP's growth. When the degree of financial development raises a unit, the vitality of GDP's growth will decline 1 percent of unit. It follows that striving to develop the financial industry and build international financial center has the positive effect on the long and stable development of china's economy.

\subsection{To Establish a Centre of RMB Products Breach an International Financial Centre}

From the construction of building international financial center, offshore banking is an important part of the international financial center. Identified to promote the construction of Shanghai international financial center and Platform for Action is that Shanghai will establish the renminbi products as a breakthrough in the construction of an international financial center, which is the first time that Shanghai clarifies its building an international financial center path from 1992 when it proposed the building of Shanghai international financial center since the national strategy.

The construction of the path is determined under the international and domestic situation, reference to international experience, advantages and disadvantages. Shanghai has basically been built into a financial market characterized by domestic financial center, and has formed a basic system through market allocation of financial resources. The gathering of financial markets has provided the trading platform and Center Construction RMB financial products. From a global perspective, international financial center will first be the location of all their financial products. In the formation and development of an international financial center which has played an important role in promoting, the national currency acts as a trading strong and growing international currency transaction. Globally, the increasingly strong demand for renminbi bonds and financial derivatives needs a unified market. Currently, RMB has become a hard currency in circulation in many countries, accelerating the establishment of RMB financial products trading center playing as foreign exchange transactions in renminbi in the world; the world will absorb the seats set up in Shanghai gathering renminbi transactions, which will effectively protect the country's financial security.

\subsection{Improving the Financial Environment, Promoting the Construction of Shanghai International Financial Centre}

Ecological theory would expand the financial structure, financial environment, finance and sustainable development issues to a question of how to improve the system under a financial control system in certain political,

Table 1. Estimate value of model accounting.

\begin{tabular}{|c|c|c|c|c|c|c|}
\hline & \multicolumn{2}{|c|}{ Estimation 1} & \multicolumn{2}{|c|}{ Estimation 2} & \multicolumn{2}{|c|}{ Estimation 3} \\
\hline \multirow{2}{*}{ Variable } & \multicolumn{2}{|c|}{ Pool Data } & \multicolumn{2}{|c|}{ Fixed Effect } & \multicolumn{2}{|c|}{ Random Effect } \\
\hline & Coefficient & Prob. & Coefficient & Prob. & Coefficient & Prob. \\
\hline Absolute & 3.260 & 0.000 & 3.311 & 0.000 & 3.287 & 0.000 \\
\hline Finance_Development & -0.010 & 0.028 & -0.011 & 0.030 & -0.011 & 0.023 \\
\hline GDP_Growth & -0.088 & 0.305 & -0.094 & 0.298 & -0.096 & 0.301 \\
\hline F-Test and Goodness of Fit & \multicolumn{2}{|c|}{$\begin{array}{c}\text { Prob (F-statistic): } \\
0.0028 \mathrm{R}^{2}: 0.28\end{array}$} & \multicolumn{2}{|c|}{$\begin{array}{c}\text { Prob (F-statistic): } \\
0.0052 \mathrm{R}^{2}: 0.28\end{array}$} & \multicolumn{2}{|c|}{$\begin{array}{c}\text { Prob (F-statistic): } \\
0.0047 \mathrm{R}^{2}: 0.28\end{array}$} \\
\hline
\end{tabular}


economic, social, cultural and legal background of the financial regulatory system, the financial market system, financial institutions, the system of financial products, and financial intermediation service system. This userfriendly formulation reflects financial humanities which have complexity, scientific, coordination, and competitiveness. Control of natural ecosystems rules and mechanisms will help us to understand the problems in the financial sector, to make us in a broader perspective to have a look at the successes and failures of financial reform, which will help promote the establishment of a more harmonious finance for financial reform and opening ecology and updated ideas, seeking a breakthrough reform.

\subsubsection{Accelerating the Improvement of the Credit system, and Creating a Good Social Credit Culture}

Establishment of full social credit system is a necessary condition for the normal operation of a modern market economy, an urgent need for full integration of the world economy. The establishment of a sound social credit system can not only improve the efficiency of economic activities, reduce transaction costs and opportunity costs, but also to help prevent financial risk, to accelerate the construction of Shanghai international financial center. On the current overall situation in terms of the credit system, there are two outstanding issues: First, the low degree of development of the credit system, especially the slow development of commercial credit among businesses; the second is social "dishonesty". The problem is more serious. There is a large number of delinquencies among enterprises, commercial banks non-performing loan problem that cannot fundamentally be resolved. There's a significant increase in economic disputes involving credit.

To solve the above problem, the integrity of the system construction can first select some relatively high level of economic development, trade credit demand urgent areas for pilot projects, giving special policies and laws, trying and paving the way for the national credit system. As China's economic center of the city, Shanghai can take the lead by the efforts to establish a social credit system. First, it can build a central foundation credit information database, and establish and improve information-sharing mechanism. Establishing a database basis involving a national unified enterprise and personal credit information, the gradual liberalization of the credit services market, the establishment of credit monitoring and penalizing bad system can be established. In this process, Shanghai should determine the technical standards and uniform credit paid credit guidelines; ensure the effective functioning of the credit system, and play its due role in risk prevention. Secondly, we must cultivate the credit rating agency owning some authority. Development of financial markets cannot be separated with a strong independent and authoritative credit rating agency. Especially the healthy development of the corporate bond market and other financial markets need credit rating agencies to act as investors to help investors identify risks, measure risk and manage risk. Next thing is to increase social awareness of the integrity of publicity to create a good social credit culture. Social consciousness is a long-term integrity which needs, all sectors of society, the broad participation of all sectors to jointly create a social atmosphere of "everyone honest". Currently, most of the payment in arrears of local government projects, government integrity and a more serious problem, therefore, the government should take the lead to do Honest Government firstly, according to the objective requirements of appropriate local economic development, not blindly seeking expanding.

\subsubsection{Speeding up Financial Market Reform, Strengthening Market Discipline, Enhancing Information Disclosure}

Development of the financial sector especially need to be reflected on "market", to play the role of market mechanisms, to encourage financial institutions to play to their strengths, conduct business, clients differentiated positioning, to encourage financial innovation, financial instruments, to support diversification of financial products and financial personalized service. Among domestic cities, Shanghai has a relatively active economic and financial, a relatively developed market operation level, a stressing that "the market" and increase the flexibility of interest rates, exchange rates and other market prices, Shanghai's financial industry is conducived to the further advantage, forming a financial service center or financial management center, including the syndicated loan center, fund settlement center, credit management centers and the like. At the same time, to strengthen market discipline and improve the information disclosure standards, prevent moral hazard and reduce financial crime, prevent financial business center into the center of the financial risk.

First we must improve the legal system and strengthen the enforcement mechanisms. Through establishing and improving these laws, you can explicitly dispose the collateral, the debtor defaulted bank debt and the implementation of an orderly bankruptcy, the maximum protection of bank debt. There are things you want to give 
absolute priority to secured claims repayment pick. Issues relating to the preservation of the debtor's property involving the basic livelihood guarantee referred to the improvement of the social security system to resolve. Prevent enterprises or individuals to use legal loopholes evasion of debts, and earnestly safeguard the financial claims. We need to strengthen law enforcement, laws and regulations to enhance deterrence, eliminating stakeholder chances. We also have to strengthen efforts to combat financial crime. Once financial professionals have malicious illegal violations, they should be held accountable, and they can never come back in the financial industry and other important industries based on blacklists and other systems again; once financial institutions and the emergence asset a misappropriation of client funds and other malicious illegal violations, we should using heavy fines, finding those responsible are held and other measures to make it hard to survive, forced to withdraw from the financial markets; meanwhile financial services consumer fraud and other illegal activities occur, we must increase the punishment to protect the interests of financial firms. To illegal financial institutions and illegal financial activities, such as underground banks, foreign exchange black market, money laundering, etc., we need to crack down and maintain social fairness and social stability [4].

\subsubsection{Establishing a Unified, Efficient and Secure Payment and Settlement System}

Payment and settlement system is one of the most important financial infrastructures. With the increasing of the business of financial institutions, financial markets, trading volume year after year, establishing a unified efficient and secure payment and settlement systems is increasingly important. Taking advantage of modern information technology, establishing and improving the different levels and functions of the payment and settlement system, which including regional clearing center, large real-time payment settlement system, small batch clearing system to meet the need of different types of financial institutions, different types of finance business.

\subsubsection{Developing Direct Financing}

We need to develop capital markets actively including both bonds and stock markets, to establish a multi-level capital market as the main direct financing system, to introduce substantial financing tool for all types of enterprises. From the business point of view, they need to take good use of consulting and information services investment banks and other intermediary agencies to create and meet market requirements of direct financing. At present, China has varieties bond including market bonds, policy financial bonds, central bank bills based. To change this pattern, we need to introduce more business financial bonds, corporate bonds, commercial paper, etc., to promote cross-market trading bonds, institutional Investor bond Market liquidity management, risk management capabilities. The stock market has to focus on the construction of basic system, letting the real development potential of the outstanding enterprises come in the domestic stock market. And improve the quality of listed companies in tangible medium and small stock investors to share the fruits of China's rapid economic growth.

\subsection{Exploiting Advantages, Featured Highlights of Shanghai}

As an international financial center to a new start, Shanghai has its subsequent advantage that people can fully grasp the depth of experience of successes and failures of major international financial center, the main operating mode of understanding international financial center, understanding of international finance conditions and ways of development center, drawing on their experience and lessons to avoid unnecessary twists and frustration.

Through this positioning, building Shanghai into an international financial center will have certain characteristics. Different from London, Hong Kong and Singapore, Shanghai has the huge domestic onshore financial markets while others have more offshore financial market advantage; meanwhile it's also different from New York's international financial center characteristics, because in a long period of time, the Shanghai international financial center can only be moderately open rather than fully open in the onshore market. Moreover in the framework of the future financial center of Shanghai, the offshore market is likely to occupy more of the New York's market share.

\subsection{Major Breakthroughs, Accelerating the Development of Market Economy the Financial System}

In the process of construction Shanghai into an international financial center, we should systematically control 
the gap between Shanghai and Hong Kong, Singapore and London, New York and other financial centers, and try to catch up by developing of comprehensive measures; but also to find the major weaknesses for improvement; not only to recognize the gap between the running surfaces of the financial markets, but also to a profound grasp of Shanghai weaknesses in the financial market fundamentals and the overall environment. So that construction Shanghai into international financial center will have a solid foundation.

From the current situation, Shanghai should make great efforts to focus on improving the market and the degree of liberalization of the economic and financial activities. This is the major gap between Shanghai and New York, London, Hong Kong, and Singapore, and also the key factors of building Shanghai into an international financial center successfully, and therefore requiring major breakthroughs. If this cannot be effectively broken, then the construction Shanghai into an international financial center, it will be difficult to achieve greater success, making it difficult to really narrow the gap among New York, London, Hong Kong and other financial centers.

\section{Acknowledgements}

This article is funded by Finance Discipline, Shanghai Second Polytechnic University, No. XXKPY1306.

\section{References}

[1] Yunnan Office (2015) The Basic Idea of Shanghai Build International Financial Centre in "Thirteen Five". http://www.gZXZ.gov.cn/Item/43300.aspx

[2] Chen, Y. (2004) China's Financial Strategy. Economy and Management Press, Beijing, 59-71.

[3] Wang, Y.P. and Zhao, Q.M. (2015) Research on Financial Development and Macroeconomic Vitality-Empirical Evidence from 214 Countries of the World. Studies of International Finance, 2, 3-13.

[4] Gao, C.C. (2007) Financial Strategy - Survival Report on International Financial Center. China Machine Press, Beijing, 466-493. 